\title{
Pengembangan Media KOPER (Kotak Permainan) pada Tema 7 Kebersamaan
}

\author{
Sofiatul Aeni1 ${ }^{*}$, Sutrisno², Qoriati Mushafanah ${ }^{3}$ \\ 123Universitas PGRI Semarang, Indonesia
}

\begin{abstract}
Abstrak
Penelitian ini bertujuan untuk mengetahui kelayakan media pembelajaran Koper (Kotak Permainan) pada Tema 7 Kebersamaan Kelas II Sekolah Dasar. Subjek penelitian siswa kelas II Sekolah Dasar Negeri Rengaspendawa 03 berjumlah 27 orang. Penelitian Research and Development (R\&D). Teknik pengumpulan data menggunakan lembar wawancara, angket analisis kebutuhan siswa dan guru. Teknik analisis data menggunakan intumen validator ahli materi dan ahli media, lembar respon guru dan siswa.Validasi ahli materi tahap pertama dengan hasil 72\% kategori "Baik"dan validasi ahli materi tahap kedua dengan hasil 93\% kategori "Sangat Baik".Validasi ahli media tahap pertama dengan hasil 72\% kategori "Baik", validasi tahap kedua dengan hasil 98\% kategori "Sangat Baik". Berdasarkan hasil validasi media dan materi terhadap media Koper dapat dinyatakan valid dan layak digunakan dalam pembelajaran Tema Kebersamaan di kelas. Hasil angket respon siswa terhadap media Koper dengan hasil 98,5\% kategori "Sangat Baik". Jadi dapat disimpulkan media Koper (Kotak Permainan) layak digunakan dalam pembelajaran di kelas.
\end{abstract}

\author{
Keywords: \\ Media Koper, $R n D$.
}

\section{PENDAHULUAN}

Perkembangan ilmu pengetahuan dan teknologi menuntut peningkatan kualitas pendidikan. Untuk meningkatkan kualitas pendidikan perlu diadakan perbaikan dalam proses pembelajaran. Proses pembelajaran merupakan kegiatan yang paling pokok dimana berhasil atau tidaknya pencapaian tujuan pendidikan bergantung pada bagaimana proses belajar yang dialami peserta didik. Berkembangnya kemajuan ilmu dalam pendidikan kini mengharuskan peran guru lebih sebagai fasilitator yang kreatif dalam menciptakan suasana belajar yang efektif, Maslikan (2017). Menurut Dewi (2017) Beragam media pembelajaran yang dapat digunakan oleh guru untuk menyampaikan materi pembelajaran kepada siswa dengan media yang bervariasi agar tidak membosankan. Ada yang mudah didapatkan dan ada pula yang sulit untuk didapatkan dan terkadang membutuhkan biaya untuk mendapatkan dan membuat media pembelajaran tersebut. Penggunaan media harus mudah diperoleh dan terjangkau harganya. Media pembelajaran memiliki banyak manfaat pula, salahsatunya adalah pembelajaran akan lebih bermakna dan menarik perhatian siswa, meningkatkan gairah belajar siswa, meningkatkan kualitas belajar, dan mempermudah komusikasi antara siswa dan guru. Menurut Triastuti (2016) Proses pembelajaran sesungguhnya merupakan salah satu bentuk komunikasi. Yang dimaksud komunikasi di sini yaitu proses penyampaian pesan/informasi dari suatu pihak (pemberi pesan) kepada pihak lain (penerima pesan). Yang berperan sebagai pemberi/penyampai pesan dalam hal ini adalah guru atau sumber belajar yang digunakan, sedangkan yang berperan sebagai penerima pesan adalah siswa. Agar lebih mudah dalam menyampaikan pesan/ informasi yang akan disampaikan, maka guru dapat sebaiknya menggunakan alat bantu berupa media. Penggunaan media dalam proses pembelajaran diharapkan dapat membantu guru dalam menyampaikan materi yang bersifat abstrak, sehingga dapat menghilangkan kesan verbalistik pada

* Corresponding author.

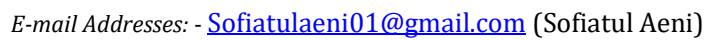


siswa. Pembelajaran yang terkesan verbalistik merupakan paradigma belajar yang lama. Paradigma belajar saat ini telah mengalami perubahan. Konsep belajar yang dahulu berpusat pada guru beralih menjadi berpusat pada siswa. Oleh karena itu guru dituntut untuk terampil dalam memilih dan menggunakan media agar siswa dapat terlibat aktif dalam pembelajaran. Dengan demikian, motivsi belajar siswa akan meningkat, dan siswa akan mendapatkan pemahaman yang lebih konkret dan lebih bermakna. Degeng (Fathurrahman 2015: 17) menyatakan bahwa "pembelajaran adalah upaya untuk membelajarkan peserta didik. Pembelajaran memusatkan pada "bagaimana membelajarkan peserta didik" dan bukan "apa yang dipelajari peserta didik". Dengan kata lain, pembelajaran merupakan upaya menciptakan kondisi agar terjadi kegiatan belajar. Proses pembelajaran yang terkendali akan memberikan dampak yang positif bagi siswa dalam proses belajar disekolah. Gagne, et al (Kurniawan 2014:27) menyatakan bahwa "pembelajaran adalah serangakaian aktivitas untuk membantu mempermudah seseorang belajar, sehingga terjadi belajar secara optimal". Sedangkan menurut Daryanto (2014:1)menyatakan bahwa "pembelajaran adalah proses interkasi antara anak dengan anak, anak dengan sumber belajar dan anak dengan pendidik". Berdasarkan pendapat para ahli dapat disimpulkan bahwa pembelajaran adalah suatu kegiatan untuk membelajarkan peserta didik untuk mempermudah seseorang dalam belajar secara baik. Proses belajar berjalan baik jika kegiatan belajar itu sendiri memberikan dampak baik bagi peserta didik dengan melibatkan siswa sebagai subjek belajar. Proses pembelajaran yang baik dapat terlaksana sangat dipengaruhi oleh sarana dan prasaran yang digunakan.

Menurut Yusuf Hadi Miarso (Sanaky 2013:3) mengatakan bahwa "media adalah segala sesuatu yang dapat digunakan untuk merangsang pikiran, perasaan, perhatian, dan kemauan siswa sehingga dapat mendorong terjadinya proses belajar pada diri pembelajaran". Menurut Kustandi dan Sutjipto (2011:8) menyatakan "media pembelajaran adalah alat yang dapat membantu proses belajar mengajar dan berfungsi untuk memperjelas makna pesan yang disampaikan, sehingga dapat mencapai tujuan pembelajaran dengan lebih baik dan sempurna". Berdasarkan pendapat para ahli dapat disimpulkan bahwa media pembelajaran adalah segala sesuatu yang dapat dijadikan perantara dalam menyampaikan pesan dalam proses pembelajaran untuk meningkatkan efektifitas dan efisiensi dalam menyampaikan materi pembelajaran sehingga tujuan pembelajaran dapat tercapai. Penggunaan media dalam pembelajaran dapat meningkatkan kualitas pembelajaran. Selain itu mempermudah siswa didalam memahami materi yang dipelajari. Media pembelajaran adalah sebuah alat yang berfungsi dan dapat digunakan untuk menyempaikan pesan pembelajaran. Jadi media pembelajaran merupakan sarana atau alat bantu pendidikan yang dapat digunakan sebagai perantara dalam proses pembelajaran untuk mempertinggi efektifitas dan efisiensi dalam mencapai tujuan pengajaran.

Berdasarkan hasil observasi dan wawancara dengan guru kelas II Sekolah Dasar di Kecamatan Larangan yang telah dilakukan peneliti pada tanggal 5-6 0ktober 2018 meliputi Sekolah Dasar Negeri Kalibanteng, Sekolah Dasar Negeri Kedungbokor 02 dan Sekolah Dasar Negeri Rengaspandawa 03 Berdasarkan tiga Sekolah Dasar yang diobservasi peneliti dapat disimpulkan sekolah mangalami keterbatasan media yang disediakan sekolah sehingga menyulitkan guru dalam menyampaikan materi pembalajaran guru sehingga guru hanya menggunakan sumber belajar dari buku guru dan buku siswa serta lingkungan sekitar sekolah saja. Berdasarkan pernyataan guru pembelajaran sudah berjalan dengan lancar setiap harinya guru sudah menggunakan model dan metode misalnya berupa ceramah, tanya jawab dan diskusi tetapi keaktifan dan kemandirian siswa dalam pembalajaran masih kurang siswa harus diberi pertanyaan terlebih dahulu baru siswa mau berbicara, masih banyak siswa yang mengalami kesulitan dalam pembelajaran dan memahami materi yang disampaikan guru terutama pada materi yang terdapat pada tema kebersamaan, siswa cenderung pasif dalam pembelajaran dan hanya mengandalkan guru sebagai sumber informasi utama, siswa kurang tertarik, mudah bosan dan kurang fokus dengan apa yang disampaikan gurunya hal ini dibuktikan dengan masih adannya siswa yang berbicara dengan teman sebelahnya saat pembelajaran berlangsung, siswa lebih suka membicarakan topik diluar materi pembalajaran tetapi apabila diberikan pertanyaan hanya sedikit siswa yang menjawab dan merespon gurunya. Masalah ini dapat terjadi dari beberapa faktor misalnya faktor dari siswanya dengan pembelajaran dikelas biasa merasa tidak ada yang menantang sehingga siswa merasa bosen selama proses pembelajaran atau siswa merasa kesulitan dalam menerima materi ataupun faktor guru yang kurang memberikan variasi dalam pembelajaran guru lebih banyak menggunakan metode yang monoton dengan karakteristik siswa SD yang suka bermain. Oleh karena itu media pembelajaran sangat diperlukan karena dapat membantu guru dalam menyampaikan materi pelajaran agar lebih efektif dan efisien. Media pembelajaran yang menarik dan sesuai dengan karakteristik siswa sangat diperlukan sebagai upaya dalam meningkatkan pemahaman siswa mengenai materi pelajaran. Dengan adanya media yang sesuai dengan karakteristik siswa dan mencakup materi pelajaran yang diajarkan berdasarkan Kompetensi Inti (KI) dan Kompetensi Dasar (KD) diharapkan mampu meningkatkan motivasi belajar siswa.

Analisis angket kebutuhan siswa dari tiga sekolah menghasilkan Tema Kebersamaan menyatakan 
bahwa media pembelajaran berupa benda konkret serta sesuai dengan karakter anak dapat membantu siswa memahami materi, memperjelas materi, serta meningkatkan keaktifan dan motivasi belajar siswa dan media dapat digunakan untuk belajar sekaligus bermain dan menciptakan pembelajaran yang menyenangkan. Sedangkan hasil analisis kebutuhan guru mengahasilkan bahwa guru sudah menggunakan kurikulum 2013 dengan menggunakan Kompetensi Inti dan Kompetensi Dasar yang sesuai, guru tidak mengalami kesulitan dalam mengajar namun dalam pembelajaran di kelas siswa kurang aktif dan antusias dalam mengikuti pelajaran, guru memerlukan media yang mencakup materi yang sesuai dengan indikator dan tujuan pembelajaran yang dapat mempermudah guru dalam menyampaikan materi, guru memerlukan media yang dapat menciptakan pembelajaran yang lebih aktif sehingga siswa lebih termotivasi dalam belajar, media yang mudah digunakan, bersifat permanen dan dapat digunakan berulang-ulang.

Berdasarkan permasalahan dan analisis angket kebutuhan guru dan siswa yang dikemukakan di atas, maka dilakukan penelitian pengembangan dengan judul "Pengembangan Media Koper pada Tema 7 Kebersamaan Kelas II Sekolah Dasar". Penelitian ini penting dilakukan mengingat pentingnya media pembelajaran yang interkatif untuk meningkatkan pemahaman dan keaktifan siswa.

\section{METODE PENELITIAN}

Metode yang digunakan adalah metode pengembangan atau Research and Development (R\&D). Penelitian dan pengembangan atau Research and Development adalah sebuah strategi atau metode penelitian yang cukup ampuh untuk memperbaiki praktik. Penelitian dan pengembangan adalah suatu proses atau langkah-langkah untuk mengembangkan suatu produk baru atau menyempurnakan produk yang telah ada, yang dapat dipertanggungjawabkan. Desain pengembangan media Koper ini dilakukan berdasarkan tahapan langkah-langkah pengembangan yang dikemukakan oleh Sugiyono (2017:409-426), yaitu: Potensi dan Masalah, Pengumpulan Informasi, Desain Produk, Validasi Desain, Revisi Desain, Uji Coba Produk, Revisi Produk, Uji Coba Pemakaian, Revisi Produk, Pembuatan Produk Masal.

Subyek penelitian studi lapangan ini adalah guru dan siswa kelas II SD N Rengaspandawa 03 dengan beberapa proses tahapan pengambilan data yang dilakukan. Dalam penelitian uji coba produk dilakukan dengan melibatkan 27 siswa.

Teknik pengumpulan data dalam penelitian ini dengan menggunakan lembar wawancara, lembar engket kebutuhan guru dan siswa serta observasi tidak terstruktur. Penelitian pengembangan ini menggunakan dua teknik analisis data yakni analisis data deskriptif kuantitatif dan analisis data deskriptif kualitatatif. Data deskriptif kuantitatif berupa hasil penilaian dan komentar oleh ahli media dan ahli materi yang kemudian akan di deskripsikan menjadi data deskriptif kualitatif yang akan menjadi bahan perbaikan produk yang dikembangkan.

Intrumen penilaian dalam penelitian pengembangan ini menggunakan skala Likert dan skala Guttman. Skala Likert digunakan pada tahap pengujian media pembelajaran Koper pada Tema 7 Kebersamaan Kelas II Sekolah Dasar untuk ahli media dan ahli materi. Sedangkan skala guttman digunakan untuk lembar analisis kebutuhan dan analisis respon siswa dikarenakan lebih mudah dipahami oleh siswa kelas II SD dengan jawaban tegas dan jelas sehingga tidak membutuhkan waktu yang lama untuk menjawab.

Penggunaan skala Likert dalam penelitian ini menggunakan beberapa pertanyaan positif dan negatif mengenai objek. Dalam butir pertanyaan mengunakan pilihan jawaban "Sangat Baik", "Baik", "Cukup Baik", " Kurang Baik" dan "Sangat Tidak Baik" dengan skala angka 5-1. Sedangakan skala guttman digunakan untuk mendapatkan jawaban yang tegas dan jelas terhadap suatu permasalahan pada butir soal dengan menggunakan jawaban "Ya" atau "Tidak".

Data yang sudah terkumpul kemudian akan dihitung berdasarkan skor yang diperoleh dengan teknik analisis data deskriptif dengan langkah-langkah sebagai berikut: Berdasarkan data yang diperoleh dari hasil validasi ahli media dan ahli materi berupa data kualitatif kemudian data dirubah dalam bentuk data kuantitatif dengan ketentuan dibawah ini.

Tabel 1. Range Presentase Kualitatif Program

\begin{tabular}{|c|c|}
\hline Keterangan & Interval \\
\hline SB (Sangat Baik) & $81-100 \%$ \\
\hline B (Baik) & $61-80 \%$ \\
\hline C (Cukup) & $41-60 \%$ \\
\hline K (Kurang) & $21-40 \%$ \\
\hline SK (Sangat Kurang) & $0-21 \%$ \\
\hline
\end{tabular}


1) Setelah data terkumpul dihitung berdasarkan data yang diperoleh dari hasil angket validasi

2) Menjumlahkan seluruh skor ideal item (reterium) untuk seluruh aspek berdasarkan angket validasi yang dibuat

3) Menghitung analisis angka penskoran dari analisis data dengan rumus sebagai berikut:

$$
P=\frac{\sum x}{\sum x i} \times 100 \%
$$

Keterangan :

$\mathrm{P} \quad=$ Presentase

$\sum x \quad=$ Jumlah skor responden

$\sum x i \quad=$ Jumlah skor ideal

$100 \%=$ Konstanta

Dari persentase yang telah diperoleh berdasarkan perhitungan selanjutnya dirubah kedalam kalimat kualitatif. Sedangkan untuk respon atau tanggapan siswa mengenai media pembelajaran dilakukan menggunakan skala guttman dengan menjawab pertanyaan yang berkaitan respon siswa terhadap media pembelajaran. Jawaban siswa bersifat tertutup yaitu dengan jawaban ya dengan skor 1 dan jawaban tidak dengan skor jawaban 0. Dengan analisis data sama seperti menggunakan skala likert.

Setelah diperolehnya data kemudian pengambilan keputusan digunakan sebagai sebagai indikator keberhasilan validasi ahli media dan ahli materi pembelajaran. Untuk validasi ahli media dan ahli materi pembelajaran hasil presentase penilaian dikatakan berhasil, valid dan praktis jika hasil perhitungan berada direntang dan kriteria 81\% - 100\% (sangat baik), 61\% - 80\% (baik), ataupun pada rentang 41\% $60 \%$ (cukup).

\section{ANALISIS DAN PEMBAHASAN}

Media pembelajaran Koper dikembangkan berdasarkan langkah-langkah penelitian pengembangan Research and Development (R\&D) dengan langkah pencarian potensi dan masalah, pengumpulan data, desain produk, validasi desain, revisi desain, dan uji coba produk. Model penelitian ini digunakan untuk menghasilkan dan menguji suatu produk tertentu. Penelitian ini bertujuan untuk menghasilkan produk media pembelajaran berupa benda konkret berbasis tematik untuk membantu dalam proses pembelajaran di kelas. Media pembelajaran yang dikembangkan berupa media Koper pada pembelajaran Tema Kebersamaan kelas II Sekolah Dasar.

Penelitian pengembangan ini dilatar belakangi oleh masih terbatasnya media pembelajaran terutama pada Tema Kebersamaan Subtema Kebersamaan di Sekolah yang tersedia di SDN Rengaspendawa 03, siswa kurang tertarik dan mudah bosan dikarenakan guru belum menggunakan media yang bervariasi dan belum sesuai dengan karakteristik anak. Sedangkan dari hasil analisis angket kebutuhan siswa, rata-rata menjawab mereka menyukai pembelajaran yang disampaikan guru, mereka menyukai jika dalam pembelajaran guru menggunakan media atau alat peraga yang dapat mempermudah mereka memahami materi, mereka menyukai media pembelajaran yang berbentuk nyata, berwarnawarni dan bisa digunakan untuk belajar sambil bermaian dalam rangka menciptakan pembelajaran yang menyenangkan dan bermakna. Sedangkan dari hasil analisis kebutuhan guru, guru berharap adanya sebuah media yang bisa meningkatkan keaktifan dan motivasi belajar siswa di kelas. Berdasarkan hasil identifikasi masalah dan penyebaran angket kebutuhan maka perlu adanya inovasi pembelajaran berupa media pembelajaran yang baru dan menarik untuk menunjang proses belajar mengajar.

Menurut Ibrahim et.al (Daryanto 2016:4) "media merupakan bentuk jamak dari kata medium. Medium dapat didefinisikan sebagai perantara atau pengantar terjadinya komunikasi dari pengirim menuju penerima". Sedangkan menurut Criticos (Daryanto 2011:4) "media merupakan salah satu komponen komunikasi, yaitu sebagai pembawa pesan dari komunikator menuju komunikan". Berdasarkan definisi tersebut maka dapat dikatakan bahwa media pembelajaran merupakan suatu alat yang digunakan sebagai perantara dalam kegaiatan pembelajaran. Sedangakan dalam dunia pendidikan media pembelajaran adalah alat atau bahan kegiatan pembelajaran. Media pembelajaran merupakan salah satu aspek penting dalam proses pendidikan dimana media pembelajaran memiliki manfat sebagai berikut: pembelajaran akan menjadi lebih menarik perhatian siswa sehingga mampu meningkatakan antusias serta motivasi belajar siswa, bahan pembelajaran akan lebih jelas dan mudah dipahami siswa 
yang memungkinkan terjadinya proses pembelajaran yang berpusat pada siswa sehingga diharapkan siswa dapat mencapai tujuan pembelajaran. Metode yang digunakan guru juga akan lebih bervariasi sehingga tidak hanya komunikasi verbal melalui metode cermah oleh guru.

Manfaat media pembelajaran, yaitu sebagai berikut: 1) Media pembelajaran dapat memperjelas materi sehingga memudahkan guru dan pesertadidik dalam proses belajar mengajar, 2) Pembelajaran menjadi lebih menarik sehingga dapat meningkatkan motivasi belajar, interkasi antar pendidik dan peserta didik, dan meningkatkan keaktifan siswa dalam belajar, 3) Dapat diaplikasikan dengan model atau strategi belajar yang bervariasi, 4) Memberikan pengalaman langsung kepada peserta didik sehingga meningkatkan kemandirian peserta didik sesuai dengan kemampuan dan minatnya sehingga pembelajaran dapat lebih bermakna, dan 5) Media pembelajaran dapat mengatasi keterbatasan indra ruang dan waktu dan menjadi lebih praktis.

Media koper yang dikembangkan oleh peneliti merupakan suatu media pembelajaran dengan bentuk, tampilan dan seluruh komponen yang disesuai dengan perkembangan siswa kelas II Sekolah Dasar. Dengan adanya hasil pengembangan berupa media Koper Tema Kebersamaan diharapkan dapat membantu guru dalam menyampaikan materi dan membantu siswa memahami materi khususnya untuk siswa kelas II semester 2 Sekolah Dasar, selain itu juga diharapkan mampu memotivasi guru untuk menggunakan media saat mengajar agar proses pembelajaran lebih efektif dan efisien.

Setelah pengembangan produk awal selesai tahap selanjutnya adalah dengan melakukan validasi terhadap media Koper dengan cara pengisian lembar angket penilaian untuk ahli materi dan ahli media, angket penilaian ahli materi terdiri dari tiga belas aspek, ahli media terdiri dari lima belas aspek dengan skor penilaian dengan menggunakan skala linkert. Hasil validasi ahli materi tahap pertama memperoleh nilai presentase $72 \%$ dengan kategori "Baik" dengan revisi dan validasi ahli materi tahap kedua memperoleh nilai dengan presentase $93 \%$ dengan kategori "Sangat Baik".

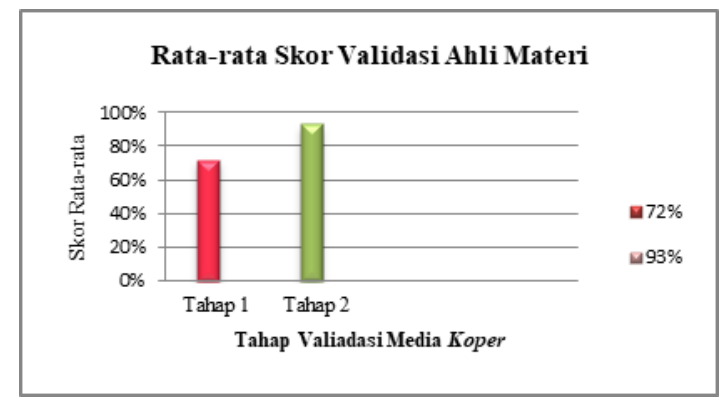

Gambar 1. Hasil Validasi Ahli Materi Dua Tahap

Hasil validasi ahli media juga dilakukan dengan dua tahap tahap pertama memperoleh presentase $72 \%$ dengan kategori "Baik" sedangkan validasi tahap kedua mempreoleh nilai dengan presentase $98 \%$ dengan kategori "Sangat Baik".

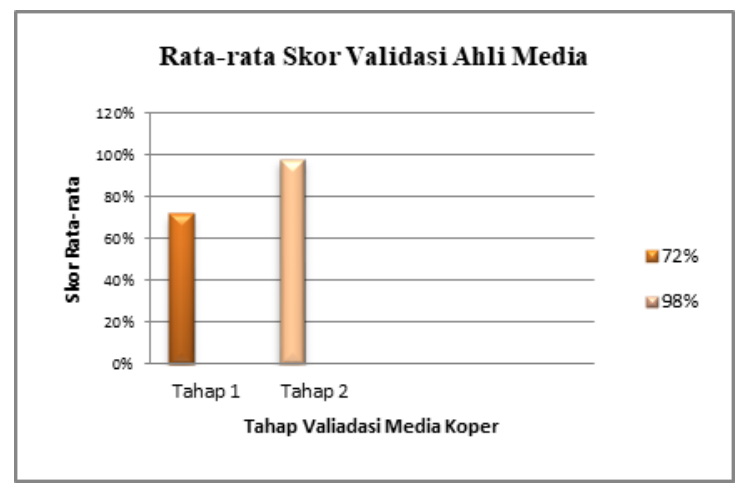

Gambar 2. Hasil Validasi Ahli Media Dua Tahap

Berdasarkan dua tahap validasi media dan materi mengalami kenaikan nilai presentase yang siginifikan dari kategori "Baik" menjadi "Sangat Baik" sehingga media Koper dapat dinyatakan valid dan 
layak digunakan dalam pembelajaran Tema Kebersamaan kelas II Sekolah Dasar. Media Koper diuji cobakan kepada 27 siswa kelas II SDN Rengaspendawa 03 dengan perolehan hasil angket respon siswa terhadap media Koper dengan presentase 98,5 \% menyukai produk yang dibuat dengan kategori "Sangat Baik". Berdasarkan hasil evaluasi yang dilakukan selama tiga kali pertemuan terhadap 27 siswa juga menghasilkan nilai hasil belajar dengan rata-rata nilai diatas KKM 65.

Pengembangan media Koper Tema Kebersamaan setelah melakukan validasi oleh ahli materi dan ahli media serta hasil respon siswa dengan perolehan hasil dengan kategori "Sangat Baik" maka pengembangan media Koper Tema Tebersamaan selesai dan memenuhi kriteria layak dan praktis untuk dipergunakan dalam pembelajaran di kelas II Sekolah Dasar.

Nilai karakter yang muncul setelah siswa belajar menggunakan media Koper Tema Kebersamaan yaitu siswa menjadi lebih aktif dan antusias mengkuti pelajaran serta lebih bersemangat dalam belajar, serta siswa terlatih untuk jujur, percaya diri, bertanggung jawab, santun dan peduli selama proses pembelajaran. Media Koper ini memilki kelebihan antara lain: media dapat digunakan berulang-ulang dan memuat materi untuk satu subtema pembelajaran, memilki warna dan komponen media yang menarik, dapat digunakan untuk belajar sambil bermain. Kekurangan media Koper ini adalah ukuran media yang relatif besar dan berat sehingga sulit dibawa kemana saja, membutuhkan biaya yang banyak dalam pembuatannya.

\section{KESIMPULAN}

Berdasarkan rumusan masalah yang dilakukan melalui penelitian dan pengembangan dapat disimpulkan bahwa: (1)Pembelajaran yang diterapkan dalam kelas sebagian besar guru belum menggunakan sarana pendukung pembelajaran seperti media pembelajaran sehingga membuat peserta didik terlihat jenuh dan bosan karena pembelajaran yang monoton dan kurang menarik, (2)media pembelajaran Koper Tema Kebersamaan dikembangkan mengacu pada langkah pengembangan R\&D menurut Sugiyono. Media yang dibuat berbahan dasar triplek tang dibalut kain flanel dengan ukuran media $60 \times 40 \times 10 \mathrm{~cm}$, (3)media Koper valid dan layak digunakan dalam pembelajaran untuk kelas II semester 1 Sekolah Dasar. Dari hasil validasi dengan perolehan nilai presentase ahli materi melalui dua tahap yakni dari 72 \% kategori "Baik" menjadi 93 \% dengan kategori "Sangat Baik". Dan validasi ahli media dengan melalui dua tahap dari nilai presentase $72 \%$ dengan kategori "Baik" menjadi 98\% dengan kategori "Sangat Baik". Dari tiga validator dengan dua tahap memperoleh kenaikan presentase yang signifikan dengan kategori sangat baik sehingga media Koper dapat dikatakan valid dan layak digunakan dalam pembelajaran di kelas, (4)media Koper memenuhi kriteria prakatis hal ini dibuktikan dengan hasil evaluasi pada tiga pertemuan terhadap 27 siswa memperoleh rata-rata nilai diatas rata-rata.

Berdasarkan dari hasil penelitian dan pengembangan yang dilakukan oleh peneliti, maka saran yang dapat diberikan terkait dengan hasil penelitian dan pengembangan media Koper Tema Kebersamaan yaitu sebagai berikut :Guru dapat menggunakan media Koper sebagai pendukung pembelajaran pada Tema Kebersamaan kelas II Sekolah Dasar, guru diharapkan menggunakan model pembelajaran lain yang lebih sesuai dengan media Koper, media Koper dapat digunakan untuk bermain sambil belajar di Sekolah Dasar, media Koper dapat digunakan untuk penelitian lanjutan.

\section{DAFTAR PUSTAKA}

Abdillah, Cahya Wahyu, 2017. Pengembangan Media Pembelajaran Koper Matematika (Kotak Perkalian) untuk Meningkatkan Kemampuan Pemecahan Masalah Matematika Siswa SD. [Skripsi]. Semarang: Universitas PGRI Semarang.

Arsyad, Azhar, 2016. Media Pembelajaran. Jakarta: Rajawali Pers.

Dahar, Wilis Ratna, 2011. Teori-Teori Belajar Dan Pembelajaran. Jakarta: Erlangga.

Daryanto. 2016 . Media Pembelajaran. Yogyakarta: Penerbit Gava Media.

Daryanto. 2014. Pembelajaran Tematik, Terpadu, Terintegrasi (Kurikulum 2013). Yogyakarta. Penerbit Gava Media

Dewi, Tipani Liani, Dadang Kurnia, Regina Lichteria Panjaitan. 2017. Penggunaan Media Permainan Ular Tangga pada Pembelajaran PIPS untuk Meningkatkan Hasil Belajar Siswa pada Materi Pembagian Wilayah Waktu di Indonesia. Jurnal Pena Ilmiah: Vol 2, No 1 Hal. 2092-2100. Tersedia Pada : http://ejournal.upi.edu/index.php/penailmiah/article/view/12425. 
Fathurrohman, Muhammad, 2015. Model-Model Pembelajaran Inovatif. Jogjakarta: Ar-Ruzz Media.

Harnanto, Sugeng. 2016. Alat Peraga Kotak Belajar Ajaib (Kobela) Dalam Pembelajaran Matematika Materi Perkalian Dan Pembagian Sekolah Dasar. Jurnal Ilmiah “PENDIDIKAN DASAR” Vol. III No. 1 Januari 2016. https://media.neliti.com/media/publications/97153-ID-alat-peraga-kotak-belajar-ajaibkobela-d.pdf. Diunduh 12-10-2018.

Istikomah, Lina, 2018. Pengembangan Media Flanel Catung (Membaca Berhitung) Tema Kegemaranku Sub Tema Gemar Berolahraga Siswa Kelas 1 SDN Cikandang 03 Brebes. [Skripsi]. Semarang: Universitas PGRI Semarang.

Kurniawan, Deni. 2014. Pembelajaran Terpadu Tematik (Teori, Praktik, Dan Penilaian). Bandung. Alfabeta.

Kustandi, Cecep dan Bambang Sutjipto. 2011. Media Pembelajaran. Bogor. Ghalia Indonesia.

Maslikan. 2017. Penggunaan Media Pembelajaran Kotak dan Kartu Misterius (Kokami) untuk Meningkatkan Aktifitas dan Ketuntasan Belajar Peserta Didik pada Pokok Bahasan Bola Volly di Kelas XII MIPA 1 SMA Negeri 2 Pekanbaru. Jurnal Pendidikan Ekonomi Akuntansi FKIP UIR Vol 5 No 2 Hal. 178-187. Tersedia Pada : http://journal.uir.ac.id/index.php/Peka/article/view/1196.

Martasera, Lutviana, 2017 Kefeektifan Media Kantong Perkalian (Koper) Terhadap Kemampuan Berhitung dalam Mata Pelajaran Matematika Kelas II SDN Tlogosari Kulon 05 Semarang. [Skripsi]. Semarang: Universitas PGRI Semarang.

Nur Fadilah, Diyah. 2018. Pengembangan Media Taktik (Kotak Tematik) Model Number Head Together Tema Diriku Kelas 1 Sekolah Dasar. Jurnal handayani vol 9, no $1 \quad 2018$. https://jurnal.unimed.ac.id/2012/index.php/handayani/article/view/10511. Diunduh 4-04-2019

Nurmarina, Anita. 2018. Pengembangan media kotak cilukba tema 1 diriku subtema 2 tubuhku kelas i sd. Jurnal sinektik Volume 1 Nomor 2, Edisi Desember 2018 Prodi PGSD Universitas Slamet Riyadi ISSN 2620-6560 (print) ISSN http://ejurnal.unisri.ac.id/index.php/sin/article/view/2799. Diunduh 4-04-2019.

Peraturan Menteri Pendidikan dan Kebudayaan Republik Indonesia Nomor 4 Tahun 2018 Tentang Penilaian Hasil Belajar oleh Satuan Pendidikan dan Penilaian Hasil Belajar oleh Pemerintah pasal 1 ayat 3. http://bsnp-indonesia.org/wp-content/uploads/2018/02/Permen-4-Tahun-2018.pdf. Di unduh 13-04-2019.

Peraturan Pemerintah Republik Indonesia Nomor 13 Tahun 2015 Tentang Perubahan Kedua Atas Peraturan Pemerintah Nomor 19 Tahun 2005 Tentang Standar Nasional Pendidikan Pasal 1 Ayat 9. https://www.unm.ac.id/files/surat/PP-No-13-Tahun-2015.pdf. Diunduh 13-4-2019.

Prilianto, Titis. 2015. Pengembangan Alat Permainan Edukatif Kokotar Untuk Pebelajaran Tematik Integratif Kelas IV Di SDN Catur Tunggal 3 Sleman Yogyakarta. Journal UNY. http://journal.student.uny.ac.id/ojs/index.php/fiptp/article/viewFile/706/685. Diunduh 4-042019.

Rusman.2015. Pembelajaran Tematik Terpadu. Depok: Raja Grafindo Persada.

Sanaky, Huair AH, 2013. Media Pembelajaran Interaktif-Inovatif. Yogyakarta: Kaukaba.

Sugiyono. 2017. Metode Penelitian Pendidikan.Bandung:Alfabeta.

Sukmadinata, Syaodah Nana, 2011. Metode Penelitian Pendidikan. Jakarta: Remaja Rosdakarya.

Sundayana, Rostina, 2015. Media Dan Alat Peraga Dalam Pembelajaran Matematika. Bandung: Alfabeta.

Triastuti, Desty, Sa'dun Akbar, Edi Bambang Irawan. 2016. Penggunaan Media Papan Permainan untuk Meningkatkan Motivasi Belajar Siswa di Sekolah Dasar. Jurnal Pascasarjana Universitas Negeri Malang Vol. 2 2 No. 1 Hal. 1-7. $\quad$ Tersedia http://pasca.um.ac.id/conferences/index.php/gtk/article/view/273/257. 